\begin{tabular}{|c|c|}
\hline \multirow{3}{*}{ 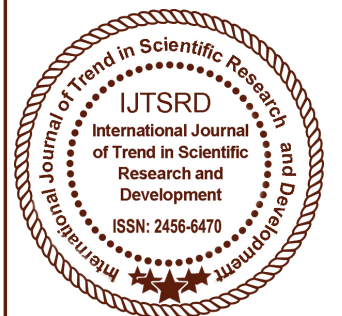 } & $\begin{array}{l}\text { International Journal of Trend in Scientific } \\
\text { Research and Development (IJTSRD) }\end{array}$ \\
\hline & International Open Access Journal \\
\hline & ISSN No: 2456 - 6470 | www.ijtsrd.com | Volume - 2 | Issue - 5 \\
\hline
\end{tabular}

\title{
Tribal Medicine Practices in Kadugolla Tribes : A Sociological Study of Chitradurga District
}

\author{
Veeresha. M \\ Resarch Scholar, Department of Sociology, Jnana \\ Sahyadri, Kuvempu University, Shankaraghatta, \\ Shivamogga, Karnataka, India
}

\author{
Dr. Krupalini H S \\ Assistant Professor, Department of Sociology, \\ Sahaydri Arts College Kuvempu University, \\ Shivamogga, Karnataka, India
}

\section{ABSTRACT}

Traditional medicine may include formalized aspects of folk medicine, that is to say longstanding remedies passed on and practiced by lay people. Folk medicine consists of the healing practices and ideas of body physiology and health preservation known to some in a culture, transmitted informally as indigenous knowledge, and practiced or applied by anyone in the culture having prior experience. In this study various medicinal practices has been observed and used by families of Chitradurga district. The tribal people like kadugolla's are used these plants to treat different diseases. The use of these herbal medicines has important role in the modern medicine system like Ayurveda, unani sidda, homeopathy, etc. The use of herbal medicine is not only cost effective but also safe and almost free from serious side effects. A total 35 medicinal plant species distributed in Chitradurga district. Nomadic-Semi nomadic tribal families are practicing this traditional medicinal system as an alternate occupation along with agriculture and animal rearing. These medicinal plants are used for headache, earache, stomach-ache, antioxidants, liver diseases, renal disease, anti- diabetic, wound infections, skin infections, fever, cough, diarrhea, eye infections, general weakness, blood purifier, to enhance immunity and other several diseases.

Keywords: Kadugolla, Nomadic Tribe, Semi nomadic Tribe, Herbal Medicine, Pashupalak

\section{INTRODUCTION}

Tribals are the original inhabitants of the world. There are many types in them. The tribal do 'pashupalak' (Rearing of animals) occupation, since their ancestors lived in the forest land. They have strong ancestral bond with the forests; they existed by rearing of animals. Today they are called Semi nomadic groups of tribal. Chitradurga is a range of south India. The range rises in regional backward areas in Karnataka state. In this district majority of the peoples are adapted to agricultural activities.

According to recent study of United Nations of organization up to $20 \%$ of the world population tribal people, they identified and leading life with their own ancestral cultural activities and ancestral pursuits. Tribal lived in forest along with rearing of animals and agriculture they also involve in preparation of baskets, furniture's, medicines using forest products. The future tribal generations also follow and continues their ancestor pursuit. Especially tribes still continued traditional medicine system of nomadic and semi nomadic community named as 'Kadugolla'. The present study concentrates how Kadugolla community continued these cultural practices.

India is well known for its plant diversity and is rich in medicinal plants wealth. India has the second largest tribal population in the world after Africa. According to the 1991 census of India, the total tribal population is $6 \%$ of country's population of which Karnataka has 51 scheduled tribe communities along with the total population of the state. The traditional medicinal practices are an important part of primary healthcare systems in the developing countries (Ghosh, 2003). As per World Health Organization (1978) report as much as $80 \%$ population of the world depends on traditional herbal medicine for 
their primary healthcare necessities (Azaizeh et al., 2003). The tribal people don't have much knowledge of the education but they have the knowledge of traditional medicines and their uses as the remedies to various diseases. This knowledge is transmitted from one generation to the next generation.

\section{METHODOLOGY:}

\section{Research topic: -}

Tribal Medicine Practices in Kadugolla Tribes: A sociological Study of Chitradurga District.

\section{Objectives:}

$>$ To study the historical background of the traditional medicine system.

$>$ To study nature of the Kadugolla tribal medicine system by using plant products.

$>$ To identification of Plant species, parts used and treating diseases.
$>$ To study different types of tribal medicine treatments in Kadugolla community.

\section{Methods of the study:}

In the present study, the field work has been carried out by using special methods in order to collect information from the tribal's regarding the various practice of traditional medicinal system. Hence I have selected some of the villages as a study area. I gathered both qualitative quantitative data through the observations, questionnaire, interview schedule, and purposive sampling. Secondary data was collected from various University libraries, literature survey and internet data.

\section{Analysis of the data:}

In my field work, I have collected qualitative and quantitative information for the analysis of information we are using for the research tools, coding, decoding, tabulation etc.

\section{Table-1: Plants used for medicinally by Nomadic or Semi nomadic tribe of Kadugolla in Chitradurga}

\begin{tabular}{|c|c|c|c|}
\hline Ailments & $\begin{array}{l}\text { Scientific/Local } \\
\text { Names and Parts } \\
\text { Used. }\end{array}$ & Medicine Preparation & Types of Treatments of Medicine. \\
\hline $\begin{array}{l}\text { Food } \\
\text { Poisoning }\end{array}$ & $\begin{array}{l}\text { Hibiscus saddariffa. } \\
\text { Khatti pendi. Sepals. }\end{array}$ & $\begin{array}{l}\text { A few sepals are boiled in a } \\
\text { glass of water. }\end{array}$ & $\begin{array}{l}\text { The infusion of sepals is given to the } \\
\text { patient which leads to vomiting. }\end{array}$ \\
\hline Epilepsy & $\begin{array}{l}\text { Commelina } \\
\text { bengalensis linn. } \\
\text { Mothi deni. Roots. }\end{array}$ & $\begin{array}{l}20 \mathrm{gm} \text { Powder of roots is } \\
\text { mixed with the equal amount } \\
\text { of jaggary and small sized } \\
\text { pills are prepared. }\end{array}$ & $\begin{array}{l}\text { Two pills in a day one in the morning } \\
\text { and one in the evening for 6-7 days in } \\
\text { case of adults and one pills in a day in } \\
\text { case children and women. }\end{array}$ \\
\hline $\begin{array}{l}\text { Prevention of } \\
\text { Pregnancy }\end{array}$ & $\begin{array}{l}\text { A)Daucus carota Linn. } \\
\text { Gajar. } \\
\text { Seeds. } \\
\text { B)Syzygium } \\
\text { heyneanun. Lahan } \\
\text { jamun. Bark. }\end{array}$ & $\begin{array}{l}70 \mathrm{gms} \text { seeds are ground to } \\
\text { powder. } \\
\text { Bark in the west side of the } \\
\text { tree is removed and } \\
\text { powdered. }\end{array}$ & $\begin{array}{l}5 \mathrm{gms} \text { seed powder is given to the } \\
\text { women twice a day for } 14 \text { day from } \\
\text { the } 4^{\text {th }} \text { day of menstruation. } \\
\text { Spoonful powder is given to the } \\
\text { women as a single dose on the } 5^{\text {th }} \text { day } \\
\text { of menstruation. }\end{array}$ \\
\hline Fistula & $\begin{array}{l}\text { Achyranthes aspera } \\
\text { Linn Aghanda. } \\
\text { Leaves. }\end{array}$ & $\begin{array}{l}\text { The leaves are crushed and a } \\
\text { paste prepared }\end{array}$ & $\begin{array}{l}\text { Leaves paste applied externally at } \\
\text { night until relief is felt. }\end{array}$ \\
\hline $\begin{array}{l}\text { Kidney } \\
\text { Stone }\end{array}$ & $\begin{array}{l}\text { Ensete superbum } \\
\text { cheesm. Jangli keli. } \\
\text { Fresh tender. }\end{array}$ & $\begin{array}{l}\text { Fresh tender peduncle is cut } \\
\text { and used }\end{array}$ & $\begin{array}{l}\text { About half foot peduncle raw it leads } \\
\text { to excessive urination and later relief } \\
\text { is felt from kidney stone. }\end{array}$ \\
\hline Diabetes & $\begin{array}{l}\text { A) Gymnema } \\
\text { Sylvestre. Bedki. } \\
\text { Fresh leaves. } \\
\text { B) Calotropis } \\
\text { gigantean. Rui. Fresh } \\
\text { flowers. }\end{array}$ & $\begin{array}{l}\text { Fresh leaves are plucked in } \\
\text { the early morning. } \\
\text { Fresh flowers are plucked in } \\
\text { the early morning }\end{array}$ & $\begin{array}{l}\text { One leaf is eaten as such in the } \\
\text { morning for } 5 \text { days. } \\
7 \text { flowers are eaten every morning for } \\
21 \text { days. }\end{array}$ \\
\hline $\begin{array}{l}\text { Skin } \\
\text { Diseases }\end{array}$ & $\begin{array}{l}\text { Cassia tora. Powadya. } \\
\text { Seeds. }\end{array}$ & $\begin{array}{l}\text { Seeds are finely powdered } \\
\text { and mixed in coconut oil to } \\
\text { prepare a paste. }\end{array}$ & $\begin{array}{l}\text { This paste is applied on affected part } \\
\text { till cured. }\end{array}$ \\
\hline
\end{tabular}


International Journal of Trend in Scientific Research and Development (IJTSRD) ISSN: 2456-6470

\begin{tabular}{|l|l|l|l|}
\hline Body Pain & $\begin{array}{l}\text { Bombax ceiba. Sawari. } \\
\text { Leaves. }\end{array}$ & $\begin{array}{l}\text { Few leaves are crushed and } \\
\text { soaked in water }\end{array}$ & $\begin{array}{l}\text { The water extract is added to hot } \\
\text { water and bath is given to the patient. }\end{array}$ \\
\hline $\begin{array}{l}\text { Asthma } \\
\text { Polio }\end{array}$ & $\begin{array}{l}\text { Helicteres isora. } \\
\text { Hedamuri. } \\
\text { Leaves,roots and bark. }\end{array}$ & $\begin{array}{l}\text { Leaves and roots are mixed } \\
\text { in a water. }\end{array}$ & $\begin{array}{l}\text { This mixture is taken twice a day till } \\
\text { cured. }\end{array}$ \\
\hline $\begin{array}{l}\text { Stomach } \\
\text { Pain }\end{array}$ & Plumeria rubra L. & $\begin{array}{l}\text { 5-10 gm. of fresh root made } \\
\text { into paste is mixed with ghee }\end{array}$ & $\begin{array}{l}\text { Administered once a day against } \\
\text { Stomach pain also cure. }\end{array}$ \\
\hline
\end{tabular}

\section{MATERIALS AND METHODS:}

The nomadic tribal in the Kadugolla's are living in Chitradurga district in Karnataka. But the data regarding tribal people and medicinal plants are collected from some parts of Chitradurga. The location of study area are Challakere, Holalkere, Hiriyur, Hosaurga etc. The tribal people were interviewed and the samples of medicines were collected. If the plants were unknown then they were identified by the exports. Most of the medicinal preparations of these tribes matched with those mentioned in Ayurveda and those medicinal preparations. More than one plant is used for same disease. The members of Tribal community were sharing the knowledge regarding traditional method of preparing the herbal medicines, local names of plants, parts used for various diseases etc.

\section{RESULT AND DISCUSSION:}

In this study, 35 medicinal plant species were studied. But some of them were given in the observation table with their method of preparation, mode of treatment, parts of plants used, scientific and local names etc. It is observed that medicinal preparations were practiced scientifically. The knowledge of herbal medicines for preparations, types of treatment to cure the diseases is transmitted one generation to another generation. The contribution of traditional medicine to the modern medicine is worth nothing. Many drugs are made by the scientists with the help of the folk knowledge of traditional medicine. Now a day the scientists are also studying the drugs against Aids, herpes, psoriasis, hypertension, jaundice, asthma, tuberculosis, leprosy, rheumatism etc.

\section{SUGGESTION:}

If we encourage the nomads medicinal practices we can cure many more diseases with their indigenous knowledge and method of practices, for this just we need to support and provide a chance to them to come up with their ideas and to implement the practice worldwide. By this we can educate them about society and make them to understand the life style of modern society.

\section{CONCLUSION:}

The study concludes that the role of herbal medicine and their role in the treatment of different diseases among the tribal peoples are crucial. This helps the agriculturist along with agriculture. This medicinal practices also benefits the rural peoples to get medicine for the various diseases free of cost, who can't able to go for highly technical treatments which costs more. They use many indigenous forest plants, flowers, roots, seeds, fruits, leaves, barks and weeds in their traditional treatment. This will benefit the improvement of traditional and cultural medicinal practices, which upholds the indigenous tradition in Global level. These peoples use plants not only medicinal practices but also in other purposes like constructions of huts, furniture's, Agricultural tools etc. If the traditional knowledge is associated with scientific and modern medicine system, it will be the new revolution in the medicine. By this practice many disease can cured easily with no effort of high technique.

\section{BIBLIOGRAPHY:}

1. Abhijit Dey, De J.N (2010) Ethno veterinary uses of medicinal plants by the Aboriginals of Purulia district, West Bengal, India. International Journal of Botany.

2. Arnold, David. (ed.) Imperial Medicine and Indigenous Societies, Delhi: Oxford University Press, 1988.

3. Ashis Ghosh, (1999) Herbal Veterinary Medicine from the Tribal Areas of Bankura District, West Bengal. J Econ Taxon Bot.

4. Binu Thomos A, Rajendran V, Aravindhan, Sivalingam R (2011) Ethno veterinary Medicines of Tribe Paniyars in Kerala, India. International Journal of Biological Technology. 
5. Ball hatchet, Kenneth. Caste, Class and Catholicism in India, 1789-1914, London: Curzon Press, 1998.

6. Ernst, W, (2002) Plural medicine, tradition and modernity, London: Routledge. Lakshmana and K.P. Sreenath, (2013) Herbal Veterinary Medicines from Kadugolla Tribes of Tumkur District, Karnataka State.

7. Kleinmann, A., (1980) Patients and healers in the context of culture. An exploration of the borderland between anthropology, medicine, and psychiatry. Berkeley: University of California Press.

8. J Gireesh and N S Raju, (2013) Ethno botanical study of medicinal plants in BR Hills region of Western Ghats, Karnataka. Department of Environmental studies, Manasa Gongotri, University of Mysore, and Karnataka, India.
9. Jain S. K., (1981). Ethno botanical research unfolds new vistas of traditional medicine, in Glimpses of Indian Ethno botany, by Jain SK (Oxford \& IBH Publishing Co Ltd, New Delhi, India).

10. Patil S.H. and Yadav S.S., (2003). Traditional medicinal plants of Satpuda, Nandurbar district Maharashtra state, Department of Indian Forester.

11. Ghosh A., (2003). Herbal folk remedies of Bankura and Medinipur districts, West Bengal (India). Indian J. Traditional Knowledge.

12. WHO (1978). Traditional Medicine, (Geneva World Health Organization Report).

13. Panikkar, K. N. "Indigenous Medicine and Cultural Hegemony: A Study of the

14. Revitalization Movement in Keralam", Studies in History, New Delhi: Sage Publications, Vol. 8, No.2, 1992 